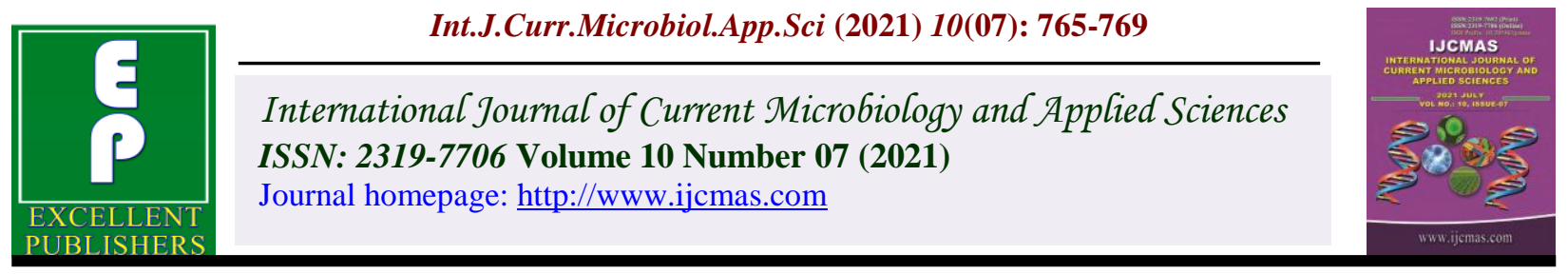

Original Research Article

https://doi.org/10.20546/ijcmas.2021.1007.083

\title{
Effect of Different Agro Chemicals on Growth, Development and Yield of Soybean (Glycine max (L.) Merril) under Rainfed Conditions
}

\author{
Jitendra Marskile, V. D. Dwivedi, S. B. Agrawal*, N.K. Bisen and Uttam Bisen \\ Jawaharlal Nehru KrishiVishwaVidhyalaya Jabalpur (M.P.) 482004, India \\ *Corresponding author
}

Keywords

Edible oil,

soybean

yield and trizophos

insecticide

Article Info

Accepted:

20 June 2021

Available Online:

10 July 2021

\section{A B S T R A C T}

Soybean (Glycine max (L.) Merril) is an important crop and it contains 40 percent protein and 20 percent edible oil, besides minerals and vitamins. The area in Madhya Pradesh under soybean is 6.26 million hectares with the production of 5.95 million tonnes. Although, the ecological conditions of the state are congenial for soybean production, however, the average yield is substantially low $(950 \mathrm{~kg} / \mathrm{ha})$, despite of follows all possible management practices (SOPA, 2014). Therefore, a field experiment conducted at experimental area of AICRP for dry land agriculture, Kuthulia farm, College of Agriculture, Rewa (M.P.) during Kharif season2015. A total of eight treatment combinations, consisted of T1: Control, T2: two spray of water at 25-30 and 55-60 DAS, T3: two foliar spray of $1 \% \mathrm{KnO}_{3}$ solutions at 25-30 and 55-60 DAS, T4: two foliar spray of $1 \% \mathrm{KCl}$ at $25-$ 30 and 55-60 DAS, T5: two foliar spray of thio-urea@ 250g/ha at 25 and 55 - 60 DAS and in 500 liter of water at 25-30 and 55-60 DAS, T6: spray of thio-urea @ 250g/ha at 25 and 55-60 DAS and trizophos insecticide@ $600 \mathrm{ml} / \mathrm{ha}$ T7: spray of 1\% KClat 25-30 and 55-60 DAS and trizophos insecticide@ $600 \mathrm{ml} / \mathrm{ha}$, T8: two spray of $1 \% \mathrm{KnO}_{3}$ solution at $25-30$ and 55-60 DAS as well astrizophos insecticide@ $600 \mathrm{ml} / \mathrm{ha}$. The result of study revealed that the application of $1 \% \mathrm{KnO}_{3}$ at $25-30$ and $55-60$ DAS followed by trizophos @ $600 \mathrm{ml} / \mathrm{ha}$ proved significantly superior closely followed by T7spray of 1\% KClat 25-30 and 55-60 DASand trizophos insecticide@600 ml/ha with respect to crop growth, Yield attributes in terms of pods/ Plant (37.18), Seeds per pod (3.13), seed index (14.13 g) as well as yields of straw (3170.2 kg/ha) and seed yield of $1390.9 \mathrm{~kg} / \mathrm{ha}$ thus it could be concluded that the spray of either $1 \% \mathrm{KnO}_{3}$ or thiourea @ $250 \mathrm{gm}$ /ha at 25-30 and 55-60 DAS followed by tryzophos@ $600 \mathrm{ml} /$ ha proved and additive for enhancing the yield of Soybean under rainfed areas. 


\section{Introduction}

Soybean (Glycine max L. Merril) is one of the commercial crop of India and have multiple qualities. It contains 40 percent protein and 20 percent edible oil, besides minerals and vitamins. In Madhya Pradesh, the area under soybean cultivation is 6.26 million hectares with the production of 5.95 million tonnes. Although, the ecological conditionsof the state are congenial for soybean production, however, the average yield is substantially low $(950 \mathrm{~kg} / \mathrm{ha})$, despite of adopted all possible management practices (SOPA, 2014). Potassium (K) considered as an essential and important nutrient for growth and development of plant. It improves the efficiency of photosynthesis and use of water. Deficiency of $\mathrm{K}$ creates a number of problems and exhibit many deficiency symptoms during plant growth like thin stem stunted growth etc. On the other hand, the seed treatment or foliar application of thio-urea or a combination of these have been shown a positive effective on growth, yield, net photosynthesis and nitrogen metabolism under rain fed conditions.

Application of thioureaeitheras pre-sowing seed treatment or as foliar spray, significantly increased plant height, leaf area, dry matter production and seed yield as compared to the untreated plants (Garg et al., 2006).Moreover, the favourable results were obtain with the combination of seed treatment with thio urea followed by foliar spray.

The beneficial effects of thio-urea were attributed to its significant role in increasing net photosynthetic rates and the concentrations of total chlorophyll and starch in the leaves. Thiourea also played a positive role in enhancing nitrogen metabolism as it significantly increased nitrate reductase activities and concentration of soluble protein in the treated plants.
The losses in the yield due to lack of plant protection measures and it varies from 46 to 96\% depending upon the type of crop plant and their variety used. The frequent application of pesticides leads to the development of resistance in the target pests. Hence, a particular pesticide has to be applied at a suitable time and dose for effective management of pests Keeping the above points in view, an experiment conducted with the object to assess the comparative performance of different agro chemicals for growth and development of soybean crop and subsequent effect on supporting system for managing biotic and abiotic stresses under rainfed conditions.

\section{Materials and Methods}

A field experiment was conducted at experimental area of AICRP for dry land agriculture, Kuthulia farm, College of Agriculture, Rewa (M.P.) during Kharif season2015. A total of eight treatment combinations, consisted of T1: Control,T2: two spray of water at 25-30 and 55-60 DAS, T3: two foliar spray of $1 \% \mathrm{KnO}_{3}$ solutions at 25-30 and 55-60 DAS, T4: two foliar spray of $1 \% \mathrm{KCl}$ at $25-30$ and 55-60 DAS, T5: two foliar spray of thio-urea@ 250g/ha dissolved in 500 litter of water at 25-30 and 55-60 DAS, T6: spray of thio-urea @ 250g/ha at $25-30$ and $55-60$ DAS and followed by spray oftrizophos insecticide@ 600 $\mathrm{ml} / \mathrm{ha}, \mathrm{T} 7$ :spray of 1\% KClat 25-30 and 55-60 DAS. Followed by spray oftrizophos insecticide@ 600 ml/ha, T8: two spray of 1\% $\mathrm{KnO}_{3}$ solutionat 25-30 and 55-60 DAS as well astrizophos insecticide@600 ml/ha.

These treatments were arranged in a randomized block design with three replications. The crop variety JS-20-29 was sown on $29^{\text {th }}$ June and $2^{\text {nd }}$ July 2015 with the seed rate of $75 \mathrm{~kg} / \mathrm{ha}$ at a $30 \mathrm{~cm}$ wide rows. Soybean crop was fertilized with $30: 60: 30 \mathrm{~kg}$ 
NPK/ha as basal dose in the form of urea, single super phosphate and murate of potash, respectively. All the package of practices were followed as per the recommendations given by the university. The crop was harvested on $3^{\text {rd }}$ October, manually with the help of sickles. Observations pertaining to plant population at 7 days after sowing, plant height $(\mathrm{cm})$, number of leaves/plant, branches/plant at an interval of 20 days, pods/plant, seed/pod and seed index as well as yields were recorded and statistically analysed for interpretation of results.

\section{Results and Discussion}

\section{Effect on crop growth}

Data pertaining to growth parameters are given in Table1. These parameters were significantly affected due to different treatments at all the growth stages of crop.

As regards to the different treatments, it was observed that the maximum plant height of 25.5, 52.24, $74.83 \mathrm{~cm}$ and $76.20 \mathrm{~cm}$ was recorded at 20, 40, 60 DAS and harvest of crop, respectively under $\mathrm{T} 8$ in which two sprays of $1 \%$ KNO3 solution was done at 2530 and 55-60 DAS and Trizophos@600 ml/ha closely followed by two foliar spray of Thiourea@250g/ha at 25-30 and 55-60 DAS +Trizophos@600 ml/ha. The number of leaves and branches/plant increased with the advancement of crop age. However, the maximization of leaves (20.74 and 18.53) and branches (3.65 and 4.31)/plant were recorded at 40 and 60 DAS respectively. Further advancement in age of crop plant from 40-60 DAS the leaves/plant decreased.

The treatment given to the experiment had significant effect on both the growth parameters viz., number of leaves as well as branches/plant. The highest counts of leaves $(20.74 \%)$ and branches (4.31) were recorded under T8 closely followed by $\mathrm{T} 7$ and $\mathrm{T} 3$. These findings are in close conformity with the finding of Bly et al., (1990), Ramesh and Thirumurugan (2001) and Reddy et al., (2004).

\section{Effect on yield attributes}

Yield attributes viz. pods/plant, seeds/pod and seed index were found significantly differ due to different treatments. The maximum values of yield attributing traits viz. No of pods (37.18 / Plant) No of seeds (3.13 / pod) and seed index (14.13 g) were recorded under T8. Whereas, the lowest counts of pods/plant (23.60/plant)seeds/pod (2.40/pod) and seed index of $12.68 \mathrm{~g}$ were recorded under control treatment.

The treatment T8, T6 and T3 found to be at par with each other for the number of pods/plant. Whereas, the treatments $\mathrm{T} 6$ and T8 in number of seeds/pod, T8, T7, T6 and T5 were found to be at par with each other for seed index. The spray of $1 \%$ KNO3 as well as Trizophos at critical period of crop provide a better growth and protection to the plant might have better development of yield attributes. Similar results have also been reported by Sindhe and Jadhav (1995) and Rahul and Parth (2015).

\section{Effects on yield}

Production of grain is a complex phenomenon which is not only depends on genetic constitution of plant but also on the production measures followed. Yields data presented in Table 2 and showed that the highest seed and straw yields of $1390 \mathrm{~kg} / \mathrm{ha}$ and $3170 \mathrm{~kg} / \mathrm{ha}$ were recorded under T8 (spray of $1 \% \mathrm{KNO} 3$ twice at an interval of 25-30 days subsequently spray of Trizophos @ $600 \mathrm{ml} / \mathrm{ha}$ ) proved superior over other treatments. 
Table.1 Effect of Treatments on Plant height, No. of leaves and branches per plant at different stages of crop growth

\begin{tabular}{|c|c|c|c|c|c|c|c|c|c|c|}
\hline \multirow[t]{2}{*}{ Treatment } & \multicolumn{4}{|c|}{ Plant height (cm) } & \multicolumn{3}{|c|}{ Number of Leaves / plant } & \multicolumn{3}{|c|}{ Number of Branches/ plant } \\
\hline & $\begin{array}{c}20 \\
\text { DAS }\end{array}$ & 40 DAS & 60 DAS & $\begin{array}{c}\text { At } \\
\text { harvest }\end{array}$ & 20 DAS & 40 DAS & 60 DAS & 20 DAS & 40 DAS & 60 DAS \\
\hline $\mathrm{T}_{1}$ : Control & 22.27 & 45.66 & 65.55 & 66.92 & 7.09 & 16.01 & 13.80 & 2.12 & 2.92 & 3.57 \\
\hline $\mathrm{T}_{2}$ : Two spray of water at $25-30$ and 55-60 DAS & 23.70 & 48.58 & 69.64 & 71.00 & 7.42 & 16.87 & 14.67 & 2.26 & 3.06 & 3.70 \\
\hline $\begin{array}{l}\mathrm{T}_{3}: \text { Two foliar spray of } 1 \% \mathrm{KnO}_{3} \text { solutions at } 25-30 \\
\text { and } 55-60 \mathrm{DAS}\end{array}$ & 24.13 & 49.46 & 70.94 & 72.31 & 7.92 & 19.34 & 17.47 & 2.39 & 3.43 & 4.08 \\
\hline $\begin{array}{l}\mathrm{T}_{4}: \text { Two foliar spray of } 1 \% \mathrm{KCl} \text { at } 25-30 \text { and } 55-60 \\
\text { DAS }\end{array}$ & 23.80 & 48.78 & 69.97 & 71.34 & 8.42 & 17.77 & 15.9 & 2.64 & 3.19 & 3.84 \\
\hline $\begin{array}{l}\mathrm{T}_{5}: \text { Two foliar spray of thio-urea @ 250g/ha at } 25 \\
\text { and 55-60 DAS and in 500 liter of water at 25-30 } \\
\text { and 55-60 DAS }\end{array}$ & 23.63 & 48.43 & 69.42 & 70.79 & 7.76 & 18.02 & 15.82 & 2.43 & 3.23 & 3.85 \\
\hline $\begin{array}{l}\mathrm{T}_{6}: \text { Spray of thio-urea @ 250g/ha at } 25 \text { and } 55-60 \\
\text { DAS and trizophos insecticide@ } 600 \mathrm{ml} / \mathrm{ha}\end{array}$ & 25.07 & 51.37 & 73.68 & 75.05 & 8.09 & 18.44 & 16.23 & 2.50 & 3.30 & 3.95 \\
\hline $\begin{array}{l}\mathrm{T}_{7}: \text { Spray of } 1 \% \mathrm{KClat} 25-30 \text { and } 55-60 \mathrm{DAS} . \text { and } \\
\text { trizophos insecticide@ } 600 \mathrm{ml} / \mathrm{ha} \text {, }\end{array}$ & 24.30 & 49.79 & 71.32 & 72.68 & 8.52 & 19.40 & 17.20 & 2.64 & 3.44 & 4.10 \\
\hline $\begin{array}{l}\mathrm{T}_{8}: \text { Two spray of } 1 \% \mathrm{KnO}_{3} \text { solution at } 25-30 \text { and } 55- \\
60 \text { DAS as well as trizophos insecticide@ } 600 \\
\mathrm{ml} / \mathrm{ha} \text {. }\end{array}$ & 25.50 & 52.24 & 74.83 & 76.20 & 9.09 & 20.74 & 18.53 & 2.85 & 3.65 & 4.31 \\
\hline SME \pm & 0.56 & 0.87 & 1.12 & 1.44 & 0.38 & 0.68 & 0.51 & 0.12 & 0.13 & 0.13 \\
\hline $\mathrm{CD}(5 \%)$ & 1.73 & 2.68 & 3.47 & 4.47 & 1.16 & 2.12 & 1.57 & 0.39 & 0.40 & 0.41 \\
\hline
\end{tabular}


Table.2 Effect of treatments on yield attributes and yields of Soybean

\begin{tabular}{|c|c|c|c|c|c|}
\hline Treatment & $\begin{array}{c}\text { No. of pods } \\
\text { per plant }\end{array}$ & $\begin{array}{c}\text { No. seeds per } \\
\text { pod }\end{array}$ & Seed Index (g) & $\begin{array}{c}\text { Seed yield } \\
\text { (Kg/ha) }\end{array}$ & $\begin{array}{c}\text { Straw yield } \\
\text { (Kg/ha) }\end{array}$ \\
\hline $\mathrm{T}_{1}$ & 23.60 & 2.40 & 12.68 & 679.65 & 2371.1 \\
\hline $\mathrm{T}_{2}$ & 29.98 & 2.53 & 12.78 & 904.76 & 2876.6 \\
\hline $\mathrm{T}_{3}$ & 34.22 & 2.65 & 13.07 & 1049.1 & 3390.4 \\
\hline $\mathrm{T}_{4}$ & 32.30 & 2.63 & 13.40 & 1018.8 & 2932.2 \\
\hline $\mathrm{T}_{5}$ & 29.99 & 2.57 & 13.53 & 952.38 & 2975.9 \\
\hline $\mathrm{T}_{6}$ & 35.51 & 3.20 & 13.46 & 1356.4 & 2954 \\
\hline $\mathrm{T}_{7}$ & 33.32 & 2.73 & 13.66 & 1089.5 & 3145.9 \\
\hline $\mathrm{T}_{8}$ & 37.18 & 3.13 & 14.13 & 1390.9 & 3170.2 \\
\hline $\mathrm{SME} \pm$ & 1.50 & 0.13 & 0.29 & 8.11 & 17.32 \\
\hline $\mathrm{CD} 5 \%$ & 4.65 & 0.39 & 0.88 & 25.12 & 13.68 \\
\hline
\end{tabular}

Whereas, the lowest yield of 679.65 and 2371 $\mathrm{kg} / \mathrm{ha}$ were recorded under control plots. This is might be due to the severe competition for nutrients right from establishment of crop uoto the end of crop growth. It leads to poor growth and development resulted in poor development of yield attributes under control plot. Whereas, treated plots(T7 and T8) attended lush growth due to better nutrition and elimination of insect incidence resulted in better development of yield attributes and consequently the higher yield. The result are in close agreement with the findings of Govindan and Thirumurugan (2000).

\section{References}

Bly, A.G.; H. J. Woodard and D. Winther(1996). Comparison of Two Sources of Potassium for Foliar Application on Soybean. 2:59-96.

Garg, B. K.; U. Burman and S. Kathju (2006). Influence of thiourea on photosynthesis, nitrogen metabolism and yield of soybean (Glycine max L.) under rainfed conditions of indian arid zone. Plant Growth
Regulation 48 (3):237-245.

Govidan K. and V. Thirumuraugan (2000). Response of green gram to foliar nutrition of potassium. Journal of Maharashtra Agricultural Universities 25:302-303.

Raddy J; N. Rao and B. K. Mahalakshmi (2004). Effect of different chemicals on growth, yield and yield attributes of pigeonpea in vertisol. Ann. Plant Physiol.17 (2):120-124.

Rahul, B. and S. D. Parth (2015). Effect of seed priming on crop growth and seed yield of soybean [Glyscine max (L.) Merrill]. The Bioscan 10(1): 265 - 270.

Ramesh, K. and V. Thirumurugan (2001). Effect of seed pelleting and foliar nutrition on growht of soybean. Madras Agric.J 88: 465 - 468.

Shinde, A.K. and B.B. Jadhav (1995). Influence of NAA, ethrel and $\mathrm{KNO}_{3}$ on leaf physiology and yield of cowpea. Ann. Plant Physiol.9:43-46.

Soybean Processer Association of India SOPA, (2014). Estimates of Soybean Crop Survey. http://www.sopa.org.

\section{How to cite this article:}

Jitendra Marskile, V. D. Dwivedi, S. B. Agrawal, N.K. Bisen and Uttam Bisen. 2021. Effect of Different Agro Chemicals on Growth, Development and Yield of Soybean (Glycine Max(L.) Merril) under Rainfed Conditions. Int.J.Curr.Microbiol.App.Sci. 10(07): 765-769. doi: https://doi.org/10.20546/ijcmas.2021.1007.083 